\title{
Evaluation of Parameters in PLA and PCL Scaffolds to be Used in Cartilaginous Tissues
}

\section{Evaluación de Parámetros en Andamios de PLA y PCL a ser Utilizados en Tejidos Cartilaginosos}

\author{
K. Cea', M. Donoso', G. Sérandour'2, , G. Martínez², L. Alegría ${ }^{4}$ \\ 'Escuela de Ingeniería Civil Mecánica, Facultad de Ciencias de la Ingeniería, Universidad Austral de Chile. \\ 2Instituto de Diseño y Métodos Industriales, Facultad de Ciencias de la Ingeniería, Universidad Austral de Chile. \\ ${ }^{3}$ LeufüLab, Facultad de Ciencias de la Ingeniería, Universidad Austral de Chile. \\ ${ }^{4}$ Centro de Docencia de Ciencias Básicas para Ingeniería, Facultad de Ciencias de la Ingeniería, Universidad Austral de Chile.
}

\begin{abstract}
The scopes of medical treatments involving organ transplants and implants for chronic problems and trauma have changed significantly. However, these procedures are subject to multiple problems. Recently, tissue engineering has been used to address them. The present study is framed in the field of tissue engineering, particularly cartilage tissue, and proposes the evaluation of geometric and impression parameters for the manufacture of scaffolds as a basis for the growth of cells through 3D impression techniques. These scaffolds are highly porous three-dimensional supports that house donated or himself patient cells, providing a surface where the cells can adhere and proliferate. In the methodology, geometric and pore size variables are defined for scaffolding modeling by using CAD techniques and standardization of the printing process with standard 3D printers and accessible materials. The results showed that material flow, printing temperature, printing speed and ventilation are the most influential parameters in the manufacture of scaffolds. Additionally, it was found micrometric variations between the modeled design and the printing result. These scaffolds will subsequently be subjected to in vitro cell culture evaluating the adherence, division, and proliferation of the cells.
\end{abstract}




\section{RESUMEN}

Los alcances de los tratamientos médicos que involucran trasplantes e implantes de órganos para problemas crónicos y traumatismos han cambiado significativamente. No obstante, dichos procedimientos están sujetos a múltiples problemáticas. Recientemente, se ha recurrido a la ingeniería de tejidos, para abordarlos. El presente estudio se enmarca en el campo de la ingeniería de tejidos, particularmente de tejido cartilaginoso, y plantea la evaluación de parámetros geométricos y de impresión para la fabricación de andamios (scaffolds) como base para el crecimiento de células a través de técnicas de impresión 3D. Dichos andamios son soportes tridimensionales altamente porosos que albergan células, pudiendo ser estas del propio paciente o donadas, proporcionando una superficie donde estas se adhieran y proliferen. En la metodología se definen variables geométricas y de tamaño de poro para modelación de los andamios mediante CAD y estandarización del proceso de impresión con impresoras 3D estándar y materiales accesibles. Los resultados mostraron que el flujo de material, la temperatura de impresión, la velocidad de impresión y la ventilación son los parámetros más influyentes en la fabricación de andamios. Adicionalmente, se encontraron variaciones micrométricas entre el diseño modelado y el resultado de la impresión. Estos andamios, posteriormente, serán sometidos a cultivo celular in vitro evaluándose la adherencia, división y proliferación de las células.

PALABRAS CLAVE: Andamio, Tejido Cartilaginoso, Impresión 3D

\section{Corresponding author}

TO: Gabriela Martínez

INSTITUTION: Universidad Austral de Chile

ADDRESS: Avenida General Lagos \#2086, Valdivia,

Los Ríos, Chile

E-MAIL: gabriela.martinez@uach.cl

\section{Received:}

28 April 2021

Accepted:

19 July 2021 


\section{INTRODUCTION}

Sometimes, different diseases or physical or chemical aggressions can lead to a loss or alteration of the cells of a tissue or organ. The normal restitution of this tissue is the main purpose of regenerative medicine ${ }^{[1]}$. Tissue engineering is a new area of regenerative medicine whose objective is the construction of in vitro tissues for a therapeutic use, that allows to restoring, replacing, or increasing the functional activities of the organic tissues themselves ${ }^{[2]}$. Basically, tissue engineering consists of growing cells in an enriched three-dimensional matrix, where these cells can grow and later be transplanted into a recipient organ ${ }^{[3]}$. Three components can be distinguished: cells, biomaterials (the extracellular matrix or supporting scaffolds) and growth factors. This paper will focus specifically on contributing information and methodologies in the construction of scaffolds for cartilaginous tissue. Among its possible applications is the aesthetic treatment of microtia, a congenital malformation of the external ear that ranges from mild structural anomalies to the complete absence of the ear, with a prevalence rate that varies significantly between countries ranging from 0.8 to 17.4 per 10,000 births, with a higher prevalencereportedinEcuadorians, Chileans and Finns, with prevalence of 17.4; 8.8 and 4.3 respectively for every 10,000 births ${ }^{[4]}$. Current cosmetic treatment options for children include reconstruction with prosthesis, combination of prosthesis and own tissue, and autologous rib cartilage transplant.

Scaffolds, which can be manufactured by 3D printing, are highly porous three-dimensional substrates that house cells, providing a surface to which they can adhere, thrive and multiply ${ }^{[5]}$; consequently, they generate an extracellular matrix (ECM) of structural and functional proteins and saccharides that form living tissue ${ }^{[6]}$. This type of structure has been used in different organs such as bone tissues or soft tissues [7]. During the last decades, much research has been carried out regarding structural capacity ${ }^{[8]}$, biocompatibility, cell growth speed ${ }^{[9]}$, shape and manufacturing process ${ }^{[10]}$, among others. These investigations have generated extensive and interesting information that has made it possible to make considerable improvements in this discipline. More recently, diverse medical sub-specialties have started considering novel 3D bioprinting approaches, based on the concept of combining living cells and biomaterials, controlling cell proliferation, attachment, and migration within 3D printed scaffolds ${ }^{[11]}$. Currently, it is possible to design and manufacture cartilage in the shape of an ear, in vitro, which is subsequently implanted under the patient's skin. However, we must consider that these are new procedures and there is still a need to improve the methodologies and materials used. For this reason, it is important to define and evaluate manufacturing parameters to guarantee the manufacture quality of scaffolds. Different parameters such as material, geometry and pore size are evaluated, indicating how the manufacturing process can alter the expected result.

Two biocompatible and biodegradable materials, polycaprolactone (PCL) and polylactic acid (PLA), were used to manufacture the scaffolds. While there are other biocompatible materials, these two materials were used primarily because they are economic, although both present different difficulties in their manufacture. These materials will generate printing parameters that can be extrapolated to other biocompatible materials with similar characteristics.

\section{MATERIALS AND METHODS}

The steps needed to allow the characterization of the necessary parameters for 3D scaffolding printing will be developed in the following section.

\section{Experiment design}

Based on the information collected from studies of the geometry importance for cell growth, the size of the manufactured pores ranged between $200 \mu \mathrm{m}$ and $600 \mu \mathrm{m}^{[2]]}{ }^{[13]}$. As for the shape, square, triangular and ellipsoidal geometries were defined. The repetitive- 
ness of the experiment was set to 6 times for each combination. This is because the printers are manually calibrated, which interferes with the equality between one scaffold and another. Coupled with this inaccuracy, it was considered the diameter variation in the of the PLA material, it is +/- $0.05 \mathrm{~mm}$ which also influences the accuracy of pore size.

\section{Design and computational modeling of scaffolding}

For the design of the PLA and PCL scaffolds, it is essential to define the following geometric parameters: $l$ (scaffold length), $p$ (pore size), $h$ (scaffold height) and $e$ (filament thickness). These parameters can be seen in Figure 1.

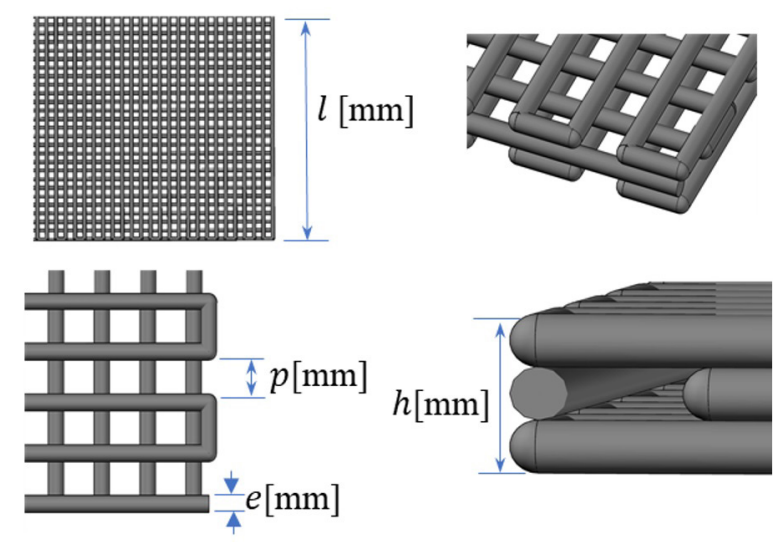

FIGURE 1. Top, three-dimensional view and dimensions (parameters) of the square scaffold. Source: self-made.

Once these parameters were defined, it was necessary to define the type of pore geometry. In this work, the geometries shown in Tables 1 and 2 were evalu-

TABLE 1. PLA scaffolding dimensions.

\begin{tabular}{c}
\hline Square \\
\hline
\end{tabular}

ated. Table 1 considers the geometries manufactured with PLA and Table 2 considers the geometries manufactured with PLC.

TABLE 2. PCL scaffolding dimensions.

\begin{tabular}{|c|c|c|}
\hline \multicolumn{3}{|c|}{ Square } \\
\hline & $\overline{4}$ & \\
\hline $\begin{array}{l}p 1=200 \mu \mathrm{m} \\
p 1=400 \mu \mathrm{m} \\
p 1=400 \mu \mathrm{m}\end{array}$ & & $\begin{array}{c}l=20 \mathrm{~mm} \\
e=400 \mu \mathrm{m} \\
h=1,2 \mathrm{~mm}\end{array}$ \\
\hline
\end{tabular}

The pore size is represented by $p$ and $b$ parameter. For square and triangular geometries three scaffolds were defined, for ellipsoidal geometry just two scaffolds were defined. Figure 2 shows the structure of triangular and ellipsoidal scaffolding.

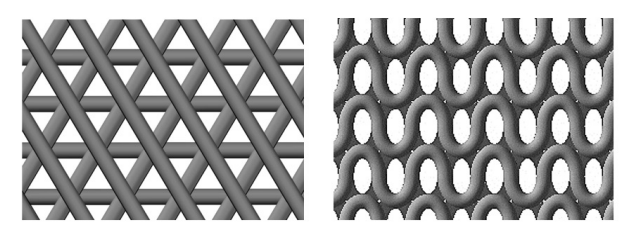

FIGURE 2. Structure of triangular and ellipsoidal scaffolding. Source: self-made.

\section{D Print}

This section shows the commercial properties of the materials to be printed, the machine considered for $3 \mathrm{D}$ printing in both PLA and PCL, in addition to the printing protocol.

\section{Materials}

Table 3 shows the characteristics of the materials used for the manufacture of scaffolding. The PLA filament, despite not having a biocompatibility certificate, was chosen because it is based on natural resins, without additives or colorants. It should be noted that the PLC has no additives or composts to be either persistent, bioaccumulative and toxic and its molecular weight in mass $\mathrm{Mw}$ is 80,000 . 
TABLE 3. Characteristics of the materials.

\begin{tabular}{ccc}
\hline Features & PLA $^{*}[\mathbf{1 4}]$ & PCL $^{*}[15]$ \\
\hline Origin & USA & USA \\
\hline Brand & 3Dxtech & Sigma-Aldrich \\
\hline Presentation & Filament & Granulated \\
\hline Material diameter & $1,75 \mathrm{~mm}+/-0,05$ & $3 \mathrm{~mm}$ \\
\hline Temp. Extrusion ${ }^{\circ} \mathbf{C}$ & $190-220$ & $54-70$ \\
\hline Color & $\begin{array}{c}\text { Without pigment } \\
\text { (natural) }\end{array}$ & $\begin{array}{c}\text { Without pigment } \\
\text { (natural) }\end{array}$ \\
\hline Density & $1,24 \mathrm{~g} / \mathrm{cc}$ & $1.145 \mathrm{~g} / \mathrm{mL}$ at $25^{\circ} \mathrm{C}$ \\
\hline Tensile Strength & $56 \mathrm{MPa}$ & - \\
\hline Tensile Modulus & $2865 \mathrm{MPa}$ & - \\
\hline $\begin{array}{c}\text { Tensile Elongation, } \\
\text { Break }\end{array}$ & $8 \%$ & - \\
\hline Flexural Strength & $178 \mathrm{MPa}$ & - \\
\hline Flexural Modulus & $3185 \mathrm{MPa}$ & - \\
\hline
\end{tabular}

*This information is indicated by the provider.

\section{Machinery}

Two types of printers were used, namely P1 and P2, for printing on PLA and PCL, respectively. Table 4 shows equipment information.

TABLE 4. Commercial characteristics

of the printers used.

\begin{tabular}{ccc}
\hline & P1 Printer & P2 Printer \\
\hline \multirow{2}{*}{ Brand } & Anet A8 & Prototype \\
& Diy Prusa I3 & "VitaPrint 3D" \\
\hline \multirow{2}{*}{ Extruder } & Brass nozzle with & 22 gauge stainless \\
& 0.2 diameter mm & steel needle \\
\hline
\end{tabular}

\section{Software used}

The following table illustrates the software used for each application (see Table 5).

TABLE 5. Software used.

\begin{tabular}{ll}
\hline Activity & Software \\
\hline $\begin{array}{l}\text { Scaffolding design in PLA and } \\
\text { PLC }\end{array}$ & Inventor Autodesk 2019॰ [16] \\
\hline $\begin{array}{l}\text { G code and PLA scaffolding } \\
\text { parameters }\end{array}$ & Ultimaker Cura 4.0.0 [17] \\
\hline $\begin{array}{l}\text { G code and PLC scaffolding } \\
\text { parameters }\end{array}$ & Repetier Host v2.1.6 [18] \\
\hline $\begin{array}{l}\text { PLA \& PCL scaffolding } \\
\text { measurement }\end{array}$ & Gwyddion 2.53 [19] \\
\hline
\end{tabular}

\section{Print care}

The environmental conditions for printing were taken into account. For this, variables such as air currents, humidity, temperature, and hygiene were considered.

\section{Scaffold Porosity Calculation}

To obtain the porosity of the PLA scaffolds, the length of the filament used in the printing of each geometry was measured and its volume is obtained by multiplying the length of the filament by its area. The area is a constant value since the filament has a diameter of $1.75 \mathrm{~mm}$. Similarly, for the PCL, the advance of the syringe embolus and its diameter is $12 \mathrm{~mm}$. It is then divided by the volume that the scaffold would occupy if it were solid (see Equation 1).

$$
P=\left(1-\frac{V i}{V S}\right) \%
$$

Where:

P: Scaffold porosity

Vi: Volume printed

Vs: Solid volume occupied by scaffolding

\section{RESULTS AND DISCUSION}

During the scaffolding generation, the environmental conditions for printing process was analyzed. During the printing, it is necessary to consider the following aspects:

- Control of air currents

The printers were encapsulated in transparent acry-lic boxes to prevent the entry of air currents that may impair the printing process and, at the same time, allow checking the status of each print without opening the box. They also decrease the possibility of entry of pathogens into the printing area. 
- Decreased air humidity

A moisture absorbing filter were placed inside the box, as humidity greatly affects the properties of the materials which can, in turn, have an impact on the print quality.

\section{- Calibration}

The printers were manually calibrated to ensure proper adhesion of the material to the base and ensure that each print is level.

- Print surface

Glass was chosen as the printing surface to facilitate cleaning and hygiene.

- Hygiene

For the printing process, special care was taken in the hygiene of all the implements and the surrounding area of the printing. For this, $70 \%(\mathrm{w} / \mathrm{v})$ alcohol were used to disinfect the workspace and tools. This concentration is the classic and agreed recommendation of the reliable methods for decontaminating surfaces ${ }^{[20]}$. Additionally, it was contemplated the use of masks and clinical gloves.

\section{- Room temperature}

This variable had a high impact on the scaffold's print quality. For the PLA case, the extruder temperature must be lowered to counteract the ambient temperature. If the ambient temperature exceeds $20^{\circ} \mathrm{C}$, the extruder temperature should be lowered beyond the limits recommended by the manufacturer. On the other hand, the PCL printing were more susceptible to variations on ambient temperature; when the temperature was below $10{ }^{\circ} \mathrm{C}$, the printing was released by retraction because the material cools too quickly, and, if the temperature exceeded $20{ }^{\circ} \mathrm{C}$, the material was kept in a viscous state for a long time, decreasing the pore size.
With consideration of those parameters, the following results are highlighted.

\section{Manufacturing remarks for PLA}

It is evidenced that it is not possible to manufacture designs with pores of $200 \mu \mathrm{m}$, because, to ensure adhesion to the glass base, the first layer of the print is wider, producing an effect that is commonly called "elephant foot". This causes the pore walls to join, which causes the pore to be "enclosed" at the bottom and not exposed on both sides of the scaffold (Figure 3).

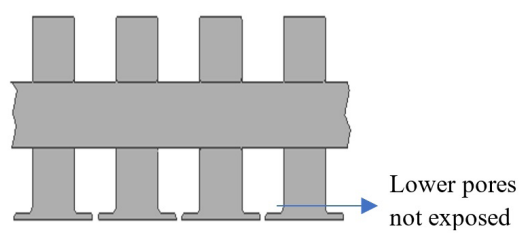

FIGURE 3. Side view of square geometry scaffolding with "elephant foot" effect (not to scale). Source: self-made.

It is possible to reduce this phenomenon by relying on Cura software ${ }^{[17]}$; however, this greatly hinders the adhesion of the material, which does not make its manufacture possible.

In the case of ellipsoidal scaffolding, it is evidenced that the way to print with precision, is to form each line with two thinner lines by using the option Special Modes-Surface: mode surface option ${ }^{[18]}$ (Figure 4(A)) The normal option (used in the other geometries) doesn't a satisfactory result (Figure 4(B)).
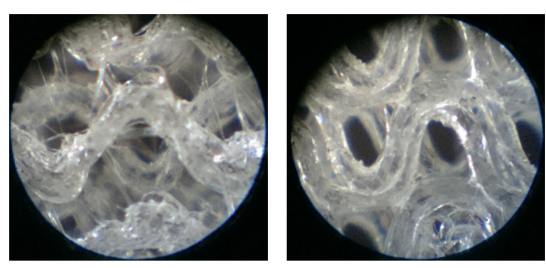

FIGURE 4. Ellipsoidal scaffolding. The images was taken from optical microscope with $\times 50$ magnification. Printed in surface option surface mode (two lines) (A). Printed in normal option surface mode (single line) (B). Source: self-made. 
This phenomenon could be because on normal option, the extruder sometimes don't print consecutively (printing the sections in Random form (Figure 5), which does not happen with the surface option.

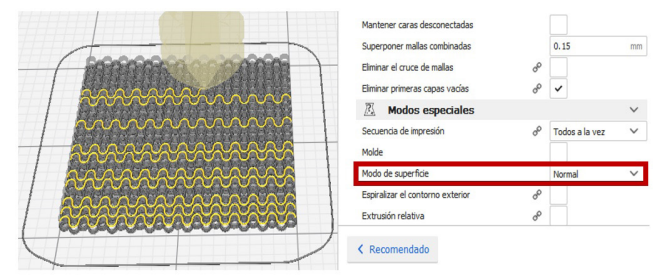

FIGURE 5. Extruder path in surface mode normal option.

The disadvantage of using two lines to form one is a thicker line results, so, the porosity of the scaffold decreases. To compensate part of this effect, the line is designed $0.01 \mathrm{~mm}$ smaller for this geometry.

\section{Print parameters for PLA}

Tables 6 and 7 show the parameters obtained for optimal printing of PLA scaffolds.

TABLE 6. Printing parameters for PLA scaffolds ${ }^{[17]}$.

\begin{tabular}{|c|c|}
\hline \multicolumn{2}{|c|}{ Common print parameters for PLA geometries } \\
\hline Parameter & Value \\
\hline Layer height (mm) & 0.1 \\
\hline Initial layer height (mm) & 0.1 \\
\hline Line width ${ }^{1}(\mathrm{~mm})$ & 0.18 \\
\hline Print plate temperature $\left({ }^{\circ} \mathrm{C}\right)$ & 60 \\
\hline $\begin{array}{l}\text { Horizontal expansion of the } \\
\text { initial layer }{ }^{2}\end{array}$ & -1 \\
\hline $\mathrm{Z}$ seam alignment ${ }^{3}$ & User specified \\
\hline Enable retraction & $\sqrt{ }$ \\
\hline Type of print plate adhesion ${ }^{4}$ & Skirt \\
\hline $\begin{array}{l}{ }^{1} \text { Line width: The width of the } \\
\text { modified to } 0.18 \mathrm{~mm} \text { to force } \\
\text { should, remembering that the } \\
\text { width used is also in } 0.18 \mathrm{~mm} \\
{ }^{2} \text { Horizontal expansion of the } \\
\text { default, this produces the effe } \\
\text { facilitate the adherence to the } \\
\text { this effect. A value less than - } \\
\text { adhere to the glass plate. } \\
{ }^{3} \mathrm{Z} \text { seam alignment: this param } \\
\text { which causes the start seems t } \\
\text { the print quality, because at th } \\
\text { deposits residues of the previc } \\
\text { dictates the alignment of the s } \\
\text { favors the scaffold's print qua } \\
{ }^{4} \text { Type of print plate adhesion: } \\
\text { scaffold, the residues of each } \\
\text { affect the scaffolding. }\end{array}$ & $\begin{array}{l}\text { ware parameters is } \\
\text { ude less material than it } \\
0.2 \mathrm{~mm} \text {, therefore the line } \\
\text { arameter is used at } 0 \text { by } \\
\text { red to as elephant foot to } \\
\text { alue }-1 \text { decreases part of } \\
\text { ible for the material to } \\
\text { lom option by default } \\
\text { any sector. This decreases } \\
\text { ch layer the extruder } \\
\text { ion specified by the user } \\
\text { point for each layer, which } \\
\text { lraws a line around the } \\
\text { posited there and not }\end{array}$ \\
\hline
\end{tabular}

TABLE 7. Differentiated printing parameters for PLA geometries ${ }^{[19]}$.

\begin{tabular}{cccc}
\hline & Square & Triangle & Ellipse \\
\hline $\begin{array}{c}\text { Line width } \\
\text { initial layer \% }\end{array}$ & 29 & 20 & 29 \\
\hline $\begin{array}{c}\text { Printing temp. } \\
(\text { \%) }\end{array}$ & 184 & 184 & 182 \\
\hline $\begin{array}{c}\text { Flow } \\
\%\end{array}$ & 92 & 92 & 92 \\
\hline $\begin{array}{c}\text { Initial layer } \\
\text { flow \% }\end{array}$ & 83 & 81 & 78 \\
\hline $\begin{array}{c}\text { Print speed } \\
(\mathbf{m m} / \mathbf{s})\end{array}$ & 23 & 23 & 9.5 \\
\hline $\begin{array}{c}\text { Ventilation } \\
\text { speed \% }\end{array}$ & 50 & 50 & 35 \\
\hline
\end{tabular}

\section{Dimensions and porosity for PLA}

\section{Geometry}

On average, all the geometries except the ellipse were approximately $50 \mu \mathrm{m}$ smaller than the computationally modeled design. For the pore size of the ellipse to agree with that of the other geometries, an overlap had to be designed as shown Figure 6. A value of $100 \mu \mathrm{m}$ was established to compensate for part of the material shrinkage.

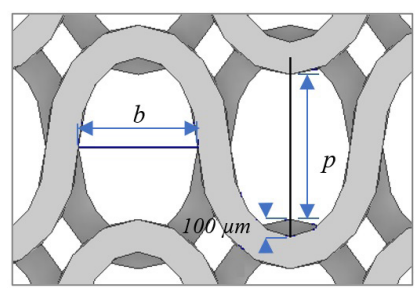

FIGURE 6. Dimensions in microns of ellipsoidal scaffolding concordant with pore. Source: self-made.

\section{Porosity}

Table 8 shows the porosity percentage achieved for each PLA scaffold.

TABLE 8. Porosities of PLA scaffolds.

\begin{tabular}{cccc}
\hline & Square & Triangle & Ellipse \\
\hline $\boldsymbol{p 1}$ & $86 \%$ & $87 \%$ & $60 \%$ \\
\hline $\boldsymbol{p 2}$ & $80 \%$ & $82 \%$ & $56 \%$ \\
\hline $\boldsymbol{p 3}$ & $73 \%$ & $78 \%$ & - \\
\hline $\boldsymbol{p 1}$ & $86 \%$ & $87 \%$ & $60 \%$ \\
\hline
\end{tabular}


Finally, figure 7 shows a magnified detail of the PLA studied geometries.
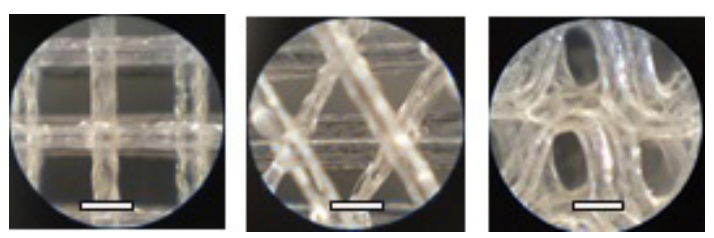

FIGURE 7. Detail of the geometries printed in PLA. Image from an optical microscope with 50x magnification. Square scaffold (A). Triangular scaffold (B). Ellipsoidal scaffold (C). Scale bars $=\mathbf{5 0 0} \mu \mathrm{m}$. Source: self-made.

\section{Manufacturing observations for PCL}

For the printing of the PCL scaffolds, it was necessary to install a hot plate on the base of the printer, to avoid the adhesion problems to the base for the rapid cooling suffered by the material. This phenomenon causes a contract and forms small drops that harden and modify the height printing. When this occurs, the needle passes through the sector again, it hits the drops, and the scaffolding comes off. Together with the previous point, other conditions to ensure surface adhesion, is the use of rough tape on the hot bed.

The pore width should be maintained between 300 and $600 \mu \mathrm{m}$ since at the lower limit the filaments are joined and at the upper limit they are cut (Figure 8).

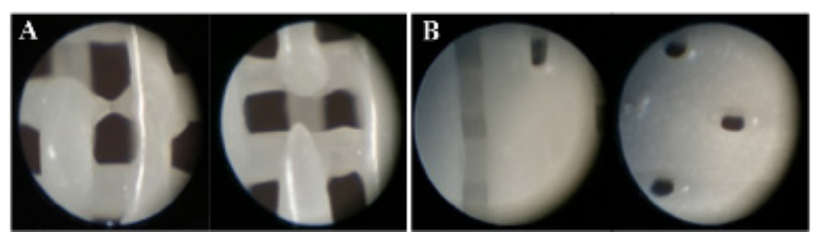

FIGURE 8. PCL scaffolding cut filaments (A), agglomerated filaments (B). The images were taken from optical microscope with $\times 50$ magnification. Source: self-made.

\section{Print parameters for PCL}

Table 9 shows the parameters obtained for optimal printing of PCL scaffolds.
TABLE 9. Printing parameters for PCL scaffolds ${ }^{[18]}$.

\begin{tabular}{|c|c|}
\hline \multicolumn{2}{|c|}{ PCL } \\
\hline Parameter & Square \\
\hline $\begin{array}{l}\text { Type of adhesion of the } \\
\text { printing plate }\end{array}$ & Skirt \\
\hline Layer Height (mm) & 0.2 \\
\hline Initial layer height (mm) & 0.2 \\
\hline Line Width (mm) & 0.3 \\
\hline Print plate temperature ${ }^{1}\left({ }^{\circ} \mathrm{C}\right)$ & $25-35$ \\
\hline Line width initial layer \% & 100 \\
\hline Syringe temperature $\left({ }^{\circ} \mathrm{C}\right)$ & 80 \\
\hline Needle temperature $\left({ }^{\circ} \mathrm{C}\right)$ & 75 \\
\hline Flow \% & 68 \\
\hline Initial layer Flow \% & 68 \\
\hline Print speed $(\mathrm{mm} / \mathrm{s})$ & 10 \\
\hline Ventilation speed $\%$ & Without ventilation \\
\hline
\end{tabular}

\section{Dimensions and porosity for PCL}

\section{Geometry}

Due to the characteristics and temperatures at which the PCL was printed, it was deposited in a liquid state, and as a result, the material spreads occupying a larger surface compared to the computationally modeled design. This results in the pores that were designed to $400 \mu \mathrm{m}$ being an average of $250 \mu \mathrm{m}$.

\section{Porosity}

Based on the above and considering the largest diameter of the extruder, the porosity was reduced to $34 \%$ for the square geometry. Figure 9 (A) shows a magnification of the final pore size. In Figure 10 it can see a 20 mm PLC scaffold.
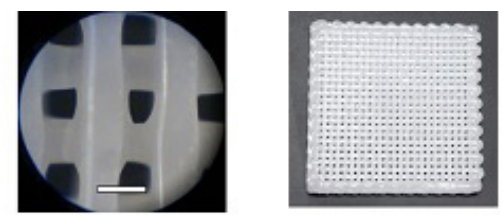

FIGURE 9. PLC Scaffold. Detail of the geometries printed in PLC. Image from an optical microscope with 50x magnification. Scale bars $=500 \mu \mathrm{m}(\mathrm{A})$. 20 mm PLC scaffold (B). Source: self-made. 


\section{CONCLUSIONS}

The three-dimensional elaboration of scaffolding for the regeneration of cartilaginous tissue represents a challenge for the existing manufacturing market devices. From this study, it is concluded:

For the equipment used in this work, the pore size of PLA must be greater than $200 \mu \mathrm{m}$ to prevent the effect called "elephant foot" enclosing the lower pores, while for manufacturing in PCL, the size of the computationally model pore should be greater than 300 $\mu \mathrm{m}$ to prevent the filament joining together and less than $600 \mu \mathrm{m}$, as the largest size, because the filaments will be cut.

It is necessary to consider the geometric design, the contraction of the geometries at least $50 \mu \mathrm{m}$ for the PLA.

Particularly, for the ellipsoidal scaffolds of PLA, an overlap had to be designed to compensate the material retraction.

In PCL material, this difference is intensified, therefore, it should be considered that the computationally designed pore, decreases by approximately $150 \mu \mathrm{m}$ in the final printed scaffold.

The extruder temperature is one of the most important variables. In PLA material, printing can be affected when the ambient temperature rises to $20^{\circ} \mathrm{C}$, the extruder temperature must be reduced below the manufacturer temperature indicates.

This is extremely important when printing is a very low speed. In PLC case, this is even more sensitive to temperatures, because it is a material that undergoes large retractions if it cools quickly, so it is necessary to implement a heat bed to the printing surface. On the other hand, the high temperature remains in a liquid state affecting the pore size.
As recommendations and future research work it is suggested:

- The cell growth in manufactured geometries could be evaluated, to observe the incidence of the geometry and/or material in cell development.

- The manufacturing options in the PLC case could be expanded, by using needles with smaller diameters, to obtain more porous scaffolds. Additionally, the possibility to combine PLC with another biocompatible material to improve its mechanical properties could be studied.

- Cell growth evaluations could be carried out in the defective manufactured scaffolds. When the computationally modeled design was not obtained, the result geometry is an interspecific and random figure. This poorly arranged patterns environment may be beneficial for cell growth.

\section{AUTHOR CONTRIBUTIONS}

K. C. Participated in the scaffold design, definition of 3D printing parameters, 3D printing of PLA scaffolds, and writing the original draft. M. D. Participated in the scaffold design, definition of 3D printing parameters, and 3D printing of PCL scaffolds. G. M. Oversaw the project supervision, experiment planning and the analysis of results, and participated in writing, reviewing, and editing the manuscript. G. S. Supervised the project supervision, as well as the $3 \mathrm{D}$ printing processes, and participated in writing, reviewing, and editing the manuscript. L. A. Par-ticipated in the material selection and writing original draft.

\section{DECLARATION OF COMPETING INTEREST}

We declare that we have no significant competing interests including financial or non-financial, professional, or personal interests interfering with the full and objective presentation of the work described in this manuscript. 


\section{ACKNOWLEDGEMENTS}

The authors want to show their appreciation to the School of Mechanical Civil Engineering of the Faculty of Engineering Sciences of the Universidad Austral de Chile for its support in the achievement of this work.
This work was funded by the FIC 1720 Project "INGOMED" with resources from the FIC Com-petitivity Innovation Fund of the Rios Region, and Installation Project of Engineering 2020-03 n: 13163235 of Vice Rectorate of Investigation, Develop-ment and Artistic Creation of the Austral University of Chile. 


\section{REFERENCES}

[1] Serrato Ochoa D, Nieto Aguilar R, Aguilera Méndez A. Ingeniería de tejidos. Una nueva disciplina en medicina regenerativa. Investigación y Ciencia [Internet]. 2015;23(64):61-9. Available from: https://www.redalyc.org/articulo.oa?id $=67441039009$

[2] Rosa V, Zhang Z, Grande RH, Nör JE. Dental Pulp Tissue Engineering in Full-length Human Root Canals. J Dent Res. 2013;92(11):970-5. Available from: https://doi.org/10.1177/0022034513505772

[3] Shapira A, Kim D-H, Dvir T. Advanced micro- and nanofabrication technologies for tissue engineering. Biofabrication. 2014;6(2):020301. Available from: https://doi.org/10.1088/1758-5082/6/2/020301

[4] Luquetti DV, Leoncini E, Mastroiacovo P. Microtia-anotia: A global review of prevalence rates. Birth Defects Res [Internet]. 2011;91(9):813-22. Available from: https://doi.org/10.1002/bdra.20836

[5] Ingber DE, Mow VC, Butler D, Niklason L, et al. Tissue Engineering and Developmental Biology: Going Biometric. Tissue Eng [Internet]. 2006;12(12):3265-83. Available from: https://doi.org/10.1089/ten.2006.12.3265

[6] Derby B. Printing and Prototyping of Tissues and Scaffolds. Science [Internet]. 2012;338(6109):921-6. Available from: https://doi.org/10.1126/science.1226340

[7] Azevedo Gonçalves Mota RC, Oliveira da Silva E, Fortes de Lima F, Rodrigues de Menezes L, et al. 3D Printed Scaffolds as a New Perspective for Bone Tissue Regeneration: Literature Review. Mat Sci and Appl [Internet]. 2016;7(8):430-52. Available from: https://doi.org/10.4236/msa.2016.78039

[8] Reboledo-Grau D, Martínez-Bordes G. Metodología para el diseñocomputacional de andamios a ser utilizados en reparación ósea. Rev UIS Ing [Internet]. 2020;19(4):301-14. Available from: https://doi.org/10.18273/revuin.v19n4-2020025

[9] Boschetti PJ, Pelliccioni O, Da Costa K, Sabino MA. Lattice Boltzmann simulation of swelling of an implant for microtia manufactured with IPN hydrogel. Comput Methods Biomech Biomed Engin [Internet]. 2020;23(1):491-9. Available from: https://doi.org/10.1080/10255842.2020.1740210

[10] Banjanin B, Vladic G, Pal M, Balos S, et al. Consistency analysis of mechanical properties of elements produced by FDM additive manufacturing technology. Rev Mater [Internet]. 2018;23(4):e12250. Available from: https://doi.org/10.1590/s1517-707620180004.0584
[11] Chiesa-Estomba CM, Aiastui A, González-Fernández I, HernáezMoya R, et al. Three-Dimensional Bioprinting Scaffolding for Nasal Cartilage Defects: A Systematic Review. Tissue Eng Regen Med [Internet]. 2021;18(3):343-53. Available from: https://doi.org/10.1007/s13770-021-00331-6

[12] Nava MM, Draghi L, Giordano C, Pietrabissa R. The Effect of Scaffold Pore Size in Cartilage Tissue Engineering. J Appl Biomater Funct Mater [Internet]. 2016;14(3):223-9. Available from: https://doi.org/10.5301/jabfm.5000302

[13] Moroni L, de Wijn JR, van Blitterswijk CA. 3D fiber-deposited scaffolds for tissue engineering: Influence of pores geometry and architecture on dynamic mechanical properties. Biomaterials [Internet]. 2006;27(7):974-85. Available from: https://doi.org/10.1016/j.biomaterials.2005.07.023

[14] 3DXTECH. Technical Data Sheet: ECOMAX® PLA 3D Printing Filament [Internet]; 2021. Available from: https://www.3dxtech.com

[15] Meck. Polylactides (PLA) [Internet]. Sigma-Aldrich; 2021. Available from: https://www.sigmaaldrich.com/MX/es/products/materialsscience/biomedical-materials/hydrophilic-polymers-

[16] Autodesk. Inventor [Internet]. Autodesk; 2019. Available from: https://www.autodesk.com/education/free-software/inventorprofessional

[17] Ultimaker. Cura 4.0.0 [Internet]. Ultimaker; 2019. Available from: https://ultimaker.com/software/ultimaker-cura

[18] Hot-World GmbH \& Co. KG. Repetier-Host v2.1.6 [Internet]. Repetier; 2019. Available from: https://www.repetier.com

[19] Czech Metrology Institute. Gwyddion 2.53 [Internet]. Gwyddion; 2019. Available from: http://gwyddion.net/download.php\#stable

[20] Graziano MU, Graziano KU, Pinto FM, Bruna CQ, et al. Effectiveness of disinfection with alcohol $70 \%$ (w/v) of contaminated surfaces not previously cleaned. Rev Latino Am. Enfermagem [Internet]. 2013;21(2):618-23. Available from: https://doi.org/10.1590/s0104-11692013000200020 